Journal of Reproduction and Development, Vol. 40, No. 2, 1994

\title{
Changes in Placental Cell Proliferation during Pregnancy in the Rabbit
}

\author{
Hiroaki HARA ${ }^{1,2)}$, and Shin-ichi SASAKI ${ }^{2)}$ \\ ${ }^{1)}$ The United Graduate School of Agricultural Science, Gifu University \\ (Shinshu University), Gifu-shi, Gifu 501-11 Japan, and \\ ${ }^{2)}$ Faculty of Agriculture, Shinshu University, Minamiminowa-mura, \\ Nagano 399-45 Japan
}

\begin{abstract}
Changes in proliferation of rabbit placental cells during pregnancy were evaluated by bromodeoxyuridine (BrdU) incorporation into the DNA. Cells were isolated and purified from rabbit placental tissues at different stages of pregnancy (day 11, 17, 23 or 29). BrdU incorporation as detected by an ELISA, indicated that cells isolated on day 11 were mitotically active in growth factor free medium. However, BrdU incorporation decreased as pregnancy progressed; this paralleled the change in placental weight gain. These results suggest that rabbit placental growth may be regulated not only by maternal factors but also by local factors.

Key words: Rabbit, Placenta, Cell proliferation, Bromodeoxyuridine.
\end{abstract}

(J. Reprod. Dev. 40: 133-139, 1994)

$\mathbf{T}$

he mammalian placenta grows rapidly during pregnancy. The placenta provides nutrition for the fetus, exchanges blood gases, allows disposal of fetal excretory material, and maintains pregnancy by a variety of hormonal mechanisms. It has been shown that the placenta is also involved in immunoprotection of the embryo [1]. The placenta is the most invasive and proliferative tissue when compared to other general tissues. Therefore, several studies have examined the roles of growth factors in placentation in humans [2] and mice [3].

The rabbit has a discoid placenta similar to humans and mice. However, its hemo-dichorial and labyrinthine structures differ from humans (hemomonochorial and villous) and mice (hemotrichorial and labyrinthine) [4]. Rabbits also have centric implantation that differs from humans which have interstitial implantation and from mice

Accepted for Publication: February 8, 1994

Correspondence: $\mathrm{S}$. Sasaki which have eccentric implantation. Thus, the morphology of rabbit placentae appears to be specific. Accordingly, a number of morphological studies have reported on rabbit placentation [5, 6]. However, no report appears to have evaluated biochemical factors involved in rabbit placental cell proliferation.

In this study we observed chronological changes in placental cell proliferation during pregnancy by bromodeoxyuridine (BrdU) incorporation into cells isolated from placental tissues on day 11 (early stage of placentation), day 17 (late stage of placentation), day 23 (fetal stage), and day 29 (the term) of pregnancy in rabbits.

\section{Materials and methods}

\section{Materials}

$\mathrm{Ca}^{2+}-\mathrm{Mg}^{2+}$ free Hanks' balanced salt solution (HBSS), Dulbecco's modified Eagle's medium 
(DMEM) and calf serum were obtained from GIBCO (Grand Island, USA). Trypsin type III, collagenase type IV, deoxyribonuclease I (DNase I), bovine serum albumin (BSA), and 5-bromo-2'deoxyuridine (BrdU) were from Sigma Chemical (St. Louis, USA). Percoll was from Pharmacia (Uppsala, Sweden). Tissue-Tek OCT compound was from Miles (Elkhart, USA). Monoclonal anticytokeratin cocktail (MAK-6) was from Triton diagnostics (Alameda, USA). Biotinylated horse antimouse IgG, avidin DH, and biotinylated horseradish peroxidase $\mathrm{H}$ reagents were from Vector Laboratories (Burlingame, USA). Flat-bottomed 96-well tissue culture plates were from Flow Laboratories (McLean, USA). Benzylpenicillin potassium and streptomycin sulfate were from Meiji-Seika (Tokyo). Pepsin was from Biozyme Laboratories (Blaenavon, UK). Anti-BrdU monoclonal antibody was from Immunotech (Marseille, France). Diaminobenzidine tetrahydrochloride (DAB) and other reagents were from Wako Pure Chemical (Osaka).

\section{Animals}

Japanese White female rabbits aged 4 months (3.3-4.0 kg body weight) were purchased from Kitayama Labes (Nagano) and mated with males of the same strain. The day of copulation was confirmed by the presence of spermatozoa in a vaginal smear and defined as day 0 of pregnancy. The rabbits were housed individually under controlled light (0500-1900 h), temperature ( $23 \pm 2 \mathrm{C})$ and relative humidity $(55 \pm 10 \%)$ and given free access to solid chow (RC4; Oriental Yeast, Tokyo) and water.

\section{Placental cell isolation}

Rabbits were euthanized by $\mathrm{CO}_{2}$ inhalation on day 11, 17, 23, or 29 of pregnancy. Live fetuses and labyrinthine zones of placentae were obtained after dissection and weighed immediately. Placental cell isolation was based on the procedure of Kliman et al. [7]. HBSS-washed placental tissue (0.3-2.2 g) was minced and digested in a twentyfold volume (vol/wt) of HBSS containing $0.25 \%$ trypsin and $0.25 \%$ collagenase for $20 \mathrm{~min}$ at $37 \mathrm{C}$ with shaking. The cell suspension was filtered through $70-\mu \mathrm{m}$ mesh and centrifuged at $250 \times \mathrm{g}$ for $5 \mathrm{~min}$. The pellet was suspended in $5 \mathrm{ml}$ of HBSS containing $20 \%$ heat-inactivated calf serum and $2 \mathrm{mM}$ EDTA to inhibit enzyme activity and centrifuged at $250 \times \mathrm{g}$ for $5 \mathrm{~min}$. The resulting pellet was resuspended in $4 \mathrm{ml}$ of DMEM containing 50 Kunitz units/ml DNase I, layered on a discontinuous Percoll gradient [70\% (2 ml), 50\% (2 $\mathrm{ml}), 30 \%(1 \mathrm{ml})$ and $20 \%(2 \mathrm{ml})$ Percoll diluted with HBSS], and centrifuged at 1,200 $\times \mathrm{g}$ for 20 min. The cells concentrated between densities 1,035 and 1,062 were removed and washed with HBSS and centrifuged at $250 \times \mathrm{g}$ for $5 \mathrm{~min}$. The final pellet was resuspended in 1-3 $\mathrm{ml}$ of DMEM containing 50 Kunitz units $/ \mathrm{ml}$ DNase I. Live cells were counted by trypan blue exclusion with an improved-Neubauer hemacytometer (Becton Dickinson, Buffalo, USA).

\section{Immunohistochemistry}

Isolated placental cells were fixed with $2 \%$ formaldehyde for $30 \mathrm{~min}$ at $4 \mathrm{C}$ and air-dried on glass slides. The uterus obtained from a day 14 pregnant rabbit was fixed with periodate-lysineparaformaldehyde fixative [8] for $20 \mathrm{~h}$ at $4 \mathrm{C}$ and washed with PBS containing sucrose (10-30\%). Implantation sites were removed from the uterus, embedded in OCT compound, frozen and stored at $-80 \mathrm{C}$. Cryostat sections $(5 \mu \mathrm{m})$ were mounted on glass slides and air-dried.

The cell preparation was immersed in $0.5 \%$ Triton X-100 in PBS for $30 \mathrm{~min}$ to permeabilize cell membranes. Cell and uterine tissue preparations were incubated with $1.5 \%$ normal horse serum in PBS for $10 \mathrm{~min}, \mathrm{MAK}-6$ for $10 \mathrm{~min}$, biotinylated horse anti-mouse IgG diluted $1 / 200$ in PBS for 10 $\min , 3 \% \mathrm{H}_{2} \mathrm{O}_{2}$ in methanol for $3 \mathrm{~min}$, avidin biotin peroxidase complex reagent for $10 \mathrm{~min}$, and $0.05 \%$ DAB and $0.01 \% \mathrm{H}_{2} \mathrm{O}_{2}$ in $0.1 \mathrm{M}$ Tris- $\mathrm{HCl}$ buffer $(\mathrm{pH}$ 7.2) for $5 \mathrm{~min}$ at $25 \mathrm{C}$. The preparations were counterstained with methylgreen. Control preparations were incubated with $1.5 \%$ normal mouse serum in PBS in place of MAK-6.

\section{BrdU incorporation}

The placental cells were placed in $100 \mu \mathrm{l} /$ well of DMEM that contained 50 Kunitz units/ml DNase I, $100 \mathrm{IU} / \mathrm{ml}$ penicillin, and $100 \mu \mathrm{g} / \mathrm{ml}$ streptomycin in the 96-well plates and were incubated in humidified $5 \% \mathrm{CO}_{2}-95 \%$ air at $37 \mathrm{C}$. Twenty-four hours later, BrdU was added to the medium, and the incubation was continued. The incorporated BrdU was detected by ELISA [9] as follows: At the end of incubation, the cells were washed twice with PBS by centrifugation of the plates at $750 \times \mathrm{g}$ for 2 
min. After air-drying the plates, the cells were fixed with $200 \mu \mathrm{l} /$ well of ethanol and air-dried again. The fixed cells were then incubated with 5 $\mathrm{mg} / \mathrm{ml}$ pepsin in $0.1 \mathrm{~N} \mathrm{HCl}$ for $30 \mathrm{~min}$ at $37 \mathrm{C}$ and, subsequently, with $4 \mathrm{~N} \mathrm{HCl}$ for $20 \mathrm{~min}$ at $25 \mathrm{C}$ to denature the DNA. Following 2 washes with 250 $\mu \mathrm{l} /$ well of $0.1 \mathrm{M} \mathrm{Na}_{2} \mathrm{~B}_{4} \mathrm{O}_{7}$ and three washes with $250 \mu \mathrm{l} /$ well of PBS, the plates were incubated with $1 \%$ BSA in PBS overnight at $4 \mathrm{C}$ for blocking. The blocking solution was discarded, and the plates were incubated with $100 \mathrm{ng} / \mathrm{ml}$ anti-BrdU monoclonal antibody in PBS, biotinylated horse antimouse IgG diluted 1/200 in PBS, and avidin biotin peroxidase complex reagent for $10 \mathrm{~min}$ each on ice. The plates were washed 3 times with $0.1 \%$ Tween 20 in PBS, and $100 \mu \mathrm{l} /$ well of substrate solution consisting of $0.4 \mathrm{mg} / \mathrm{ml} \mathrm{o}$-phenylenediamine and $0.009 \% \mathrm{H}_{2} \mathrm{O}_{2}$ dissolved in $0.1 \mathrm{M}$ citric acid$\mathrm{Na}_{2} \mathrm{HPO}_{4}$ buffer (pH 5.0) was added. After incubation for $20 \mathrm{~min}$ at $25 \mathrm{C}$, the reaction was terminated by adding $25 \mu \mathrm{l} /$ well $8 \mathrm{~N} \mathrm{H}_{2} \mathrm{SO}_{4}$. Absorbance was measured by reading the plates at 492 $\mathrm{nm}$ in a Titertek Multiskan MCC (Flow Laboratories, McLean, USA). All measurements were made in triplicate.

Optimal conditions for detecting incorporated BrdU were examined by varying exposure times $(1,5,24 \mathrm{~h})$, BrdU concentrations $\left(10^{-5}-10^{-3} \mathrm{M}\right)$, and cell counts (5000-80000/well) using placental

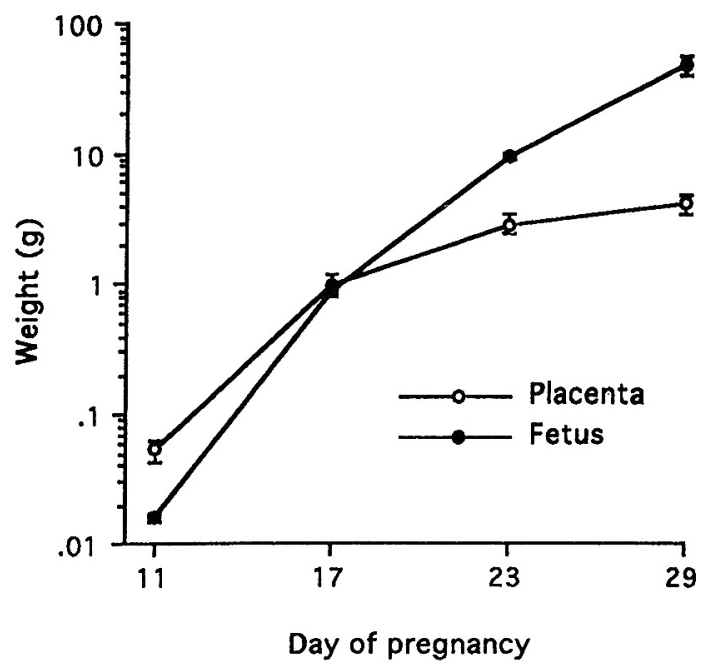

Fig. 1. Changes in fetal and placental weights during pregnancy in rabbits. All data represent the mean \pm SD of four pregnant rabbits. cells prepared from a specimen on day 11 of pregnancy. Based on these results, 20000 cells/well incubated with $10^{-4} \mathrm{M}$ BrdU for 24 hours were found to be optimal and, hence, were used in the present experiment.

\section{Statistical analysis}

The absorbance values were analyzed among days of pregnancy by one-way analysis of variance followed by the least significant difference method. $\mathrm{P}<0.05$ was considered to be significant.

\section{Results}

Changes in fetal and placental weights are given in Fig. 1. The gain in placental weight reached plateau in the late stage of pregnancy in contrast with fetal growth that continued to the end of pregnancy. Viability of the collected cells, based on trypan blue exclusion, was greater than $90 \%$. Yield of live cells per $1 \mathrm{~g}$ wet weight of placental tissue was between 7.72 (day 11) and 4.84 (day 29) $\times 10^{6}$. The yield tended to decrease as pregnancy progressed, but the difference was not significant among these days of pregnancy. The majority of collected cells were mononuclear with a 10-20 $\mu \mathrm{m}$ diameter (Fig. 2). There were polynuclear and giant cells with a diameter of more than $30 \mu \mathrm{m}$, but they were less than $5 \%$ of total cell count. These morphological characteristics did not change from day 11 to 29 of pregnancy.

Immunohistochemical staining of uterine tissue

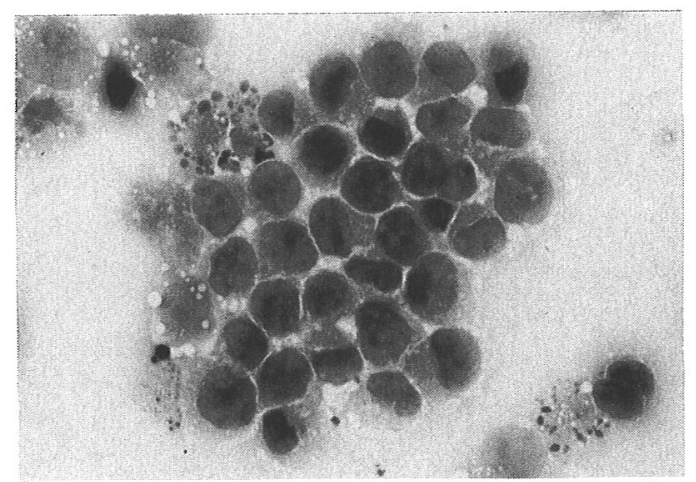

Fig. 2. Cells dispersed from rabbit placenta on day 11 of pregnancy, concentrated between densities 1.035 and 1.062 of Percoll gradient, fixed with $2 \%$ formaldehyde, and stained with hematoxylin-eosin. Magnification, $\times 426$. 
with cytokeratin antibody revealed positive reactions with the fetal placenta, such as the placental labyrinth and junctional zone, but a negative reaction occurred in the decidua (Fig. 3a). Cells isolated from day 11-29 placentae also showed positive staining in all cells observed including the giant cells (Fig. 3c).

A linear correlation between BrdU exposure time and absorbance was noted up to $24 \mathrm{~h}$ in day 11 placental cells (Fig. 4a). The absorbance linked to BrdU concentration increased linearly from $10^{-5}$ to $4 \times 10^{-5} \mathrm{M}$ then reached its plateau at $10^{-4} \mathrm{M}$ (Fig. 4b). Absorbance was also dependent on cell count; it increased linearly from 5000 to 20000 cells/well and then reached its plateau at 40000 cells/well (Fig. 4c). According to these results, 20000 placental cells per well were incubated with $10^{-4} \mathrm{M}$ BrdU for 24 hours to compare BrdU incorporation among days $11,17,23$, and 29 of pregnancy. The cells on day 11 showed the greatest incorporation of $\mathrm{BrdU}$ with $1.12 \pm 0.08$ (mean $\pm \mathrm{SD}$, $\mathrm{n}=4$ ) absorbance at $492 \mathrm{~nm}$. BrdU incorporation decreased to $0.40 \pm 0.04$ on day 17 and then to 0.25 \pm 0.03 on day 23 . Finally, the cells on day 29 did not show measurable incorporation of BrdU. Thus, $\mathrm{BrdU}$ incorporation decreased with the progress of pregnancy (Fig. 5), and the differences were statistically significant among all days observed.

\section{Discussion}

The placenta in rabbits appears on the decidua on day 9 of pregnancy [5]; it then develops and completes its hemo-dichorial labyrinth by day 18 [6]. Changes in placental weight show that placental growth in rabbits is rapid up to day 17 of pregnancy but reaches plateau after day 23 in contrast to fetal growth. This finding is consistent with a morphological observation of rabbit placentation by Kotera [6].

Iguchi et al. [10] reported that trophoblastic cells from murine placentae on day 6 to 18 of pregnancy increased in number when cultured in medium containing $10 \%$ fetal bovine serum for 18 days but did not proliferate in serum free medium. Cell proliferation in culture requires specific conditions, and, hence, medium composition and cell attachment vary for each type of cells. Accordingly, we assessed the proliferation potency of rabbit placental cells using BrdU incorporation into the DNA as an index of DNA synthesis. Despite the absence of growth factor in the medium, the isolated rabbit placental cells on day 11 of pregnancy actively incorporated BrdU into the DNA. The incorporated BrdU decreased with the progress of pregnancy, which in turn, appears to be related to the change in placental weight gain.
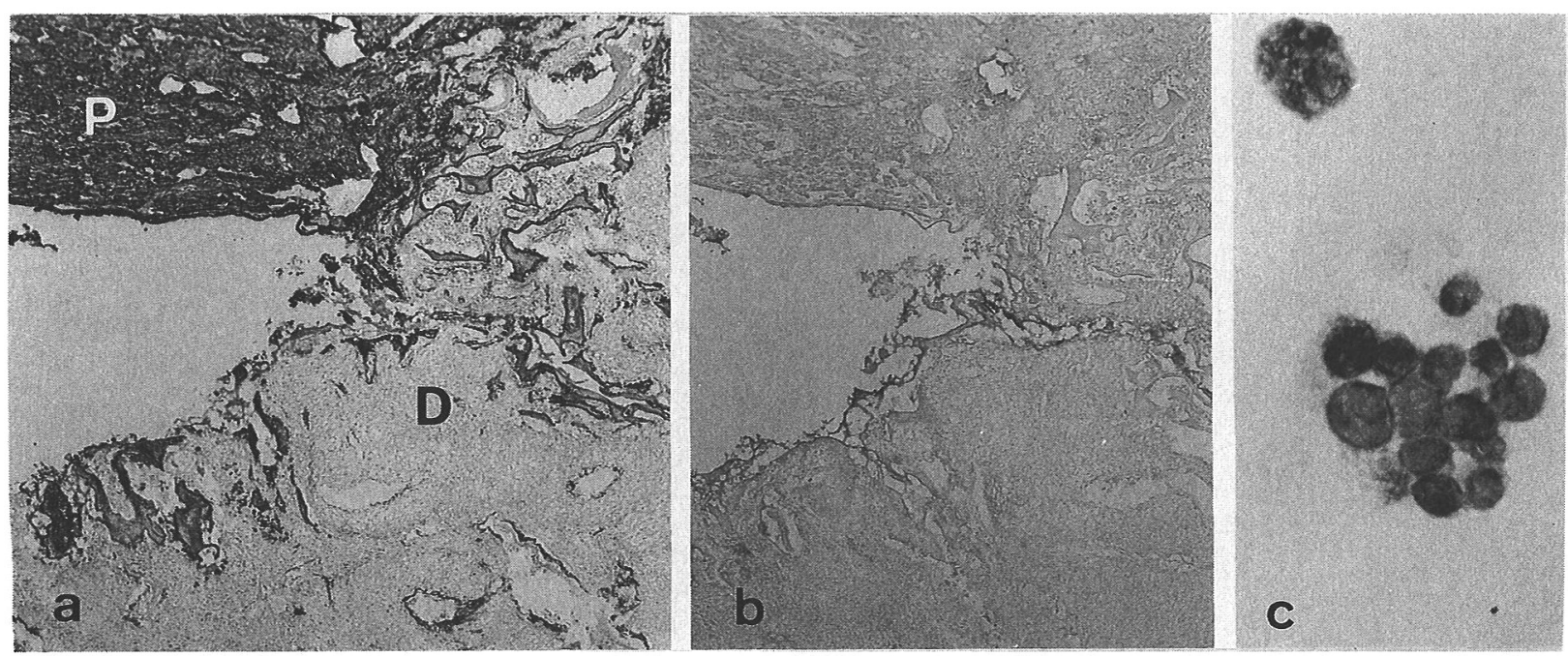

Fig. 3. Placental tissue and cells stained immunohistochemically with cytokeratin antibody. a) Implantation site of day 14 pregnant rabbit. Placental labyrinth (P) shows positive, but decidua (D) shows negative. Magnification, $\times 43$. b) Negative control treated with $1.5 \%$ normal mouse serum. Magnification, $\times 43$. c) Cells from a placenta on day 11 of pregnancy show positive. Magnification, $\times 426$. 


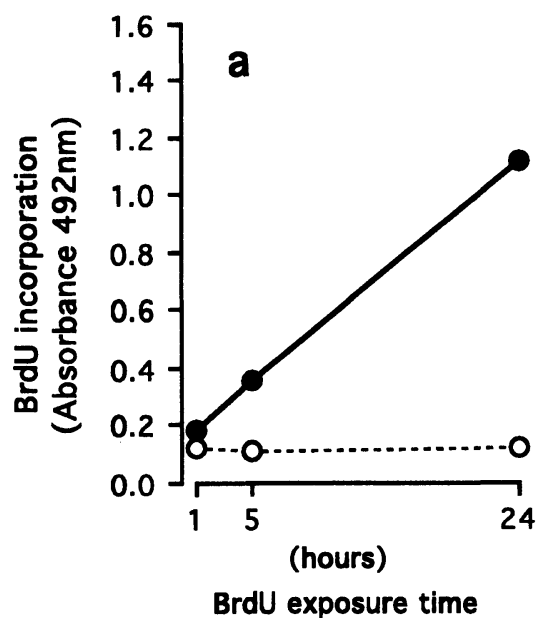

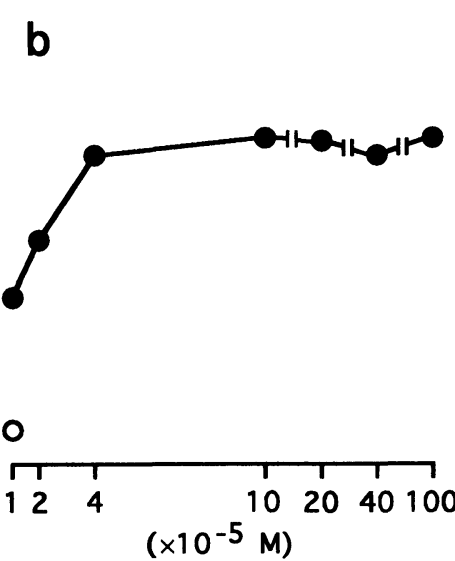

BrdU concentration

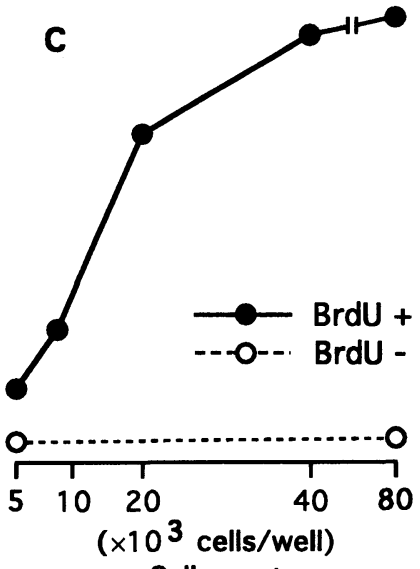

Cell count

Fig. 4. Effect of a) BrdU exposure time, b) BrdU concentration and c) cell count on BrdU incorporation into isolated rabbit placental cells on day 11 of pregnancy. The cells were preincubated in DMEM for $24 \mathrm{~h}$. Basal conditions were $10^{-4} \mathrm{M}$ BrdU, exposure for $24 \mathrm{~h}$, and 20000 cells/well. Incorporated BrdU was detected by an ELISA.

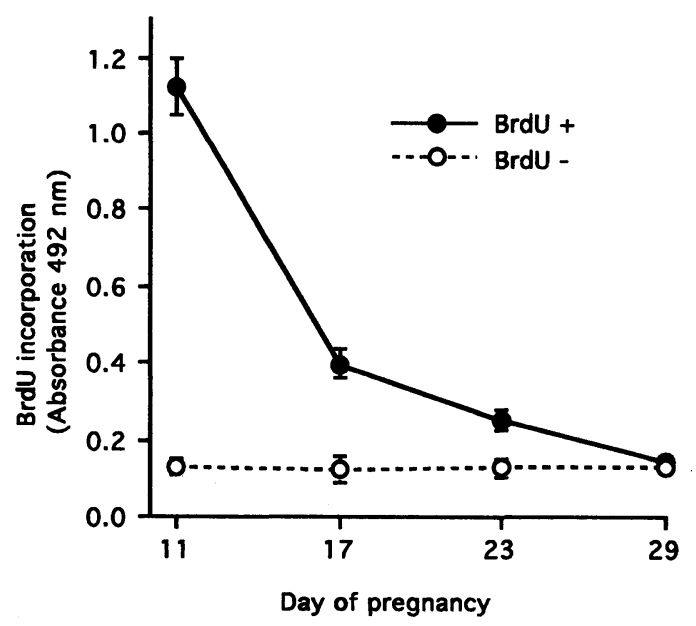

Fig. 5. Changes in BrdU incorporation into isolated rabbit placental cells during pregnancy. The cells $(20000 /$ well) were preincubated in DMEM for $24 \mathrm{~h}$ and exposed to $10^{-4} \mathrm{M}$ BrdU for another $24 \mathrm{~h}$. The incorporated BrdU was detected by an ELISA. All data represent the mean \pm SD of 4 pregnant rabbits. The difference between all days is significant $(\mathrm{P}<0.01)$.

These results, therefore, suggest that rabbit placental growth may be regulated not only by maternal factors but also by local factors.

Purification of cytotrophoblasts from human term placentae by trypsin digestion and Percoll gradient centrifugation has been reported by
Kliman et al. [7]. A combination of trypsin and collagenase was used for enzymatic digestion in this study because a small number of cells were obtained from trypsin-digested tissues in our preliminary experiments (data not shown).

It has been demonstrated that cytotrophoblasts specifically react to cytokeratin antibody in the mouse [10], the rhesus monkey [11], and the human [12]. In the rabbit, placental tissue derived from the fetal region, but not maternal, showed positive immunohistochemical staining with a monoclonal cytokeratin antibody (MAK-6). Similarly, the isolated rabbit placental cells had positive staining with MAK- 6 and were identified as trophoblastic cells. These results suggest that this method is suitable for purifying placental cells from rabbit placenta.

Measurement of BrdU incorporation into the DNA using BrdU antibody has been useful for assessment of cell proliferation $[9,13]$. When day 11 isolated rabbit placental cells were incubated with $\mathrm{BrdU}$, and the incorporated BrdU was detected by means of ELISA, absorbance increased depending exposure time, BrdU concentration, and cell count. Therefore, absorbance appears to adequately reflect the quantitative assessment of cell proliferation in rabbit placental cells.

Specific receptors to growth factors, such as epidermal growth factor (EGF) [14-17], insulin-like growth factors (IGFs) [18, 19], colony-stimulating 
factor-1 [20], granulocyte colony-stimulating factor [21], tumor necrosis factor [22], and insulin [23, 24] have been found in the human placenta. These maternal factors have been recognized as regulators of placental growth. There are also several reports suggesting the autocrine control of human placental growth [25-27]. Although our study suggests the possibility of autonomous regulation of placental growth in the rabbit, the regulatory mechanisms for rabbit placental growth remain to be elucidated.

\section{References}

1. Lea RG, Clark DA. Macrophages and migratory cells in endometrium relevant to implantation. Bailliére's Clin Obstet Gynaecol 1991; 5: 25-59.

2. Maruo T, Matsuo $H$, Murata $K$, Mochizuki M. Gestational age-dependent dual action of epidermal growth factor on human placenta early in gestation. J Clin Endocrinol Metab 1992; 75: 1362-1367.

3. Kanai-Azuma M, Kanai $Y$, Kurohmaru M, Sakai S, Hayashi Y. Insulin-like growth factor (IGF)-I stimulates proliferation and migration of mouse ectoplacental cone cells, while IGF-II transforms them into trophoblastic giant cells in vitro. Biol Reprod 1993; 48: 252-261.

4. Björkman N, Dantzer V, Leiser R. Comparative placentation in laboratory animals a review. Scand J Lab Anim Sci 1989; 4: 129-158.

5. Hafez ESE, Tsutsumi Y. Changes in endometrial vascularity during implantation and pregnancy in the rabbit. Am J Anat 1966; 118: 249-282.

6. Kotera K. Histological observation of the chronological changes in the constituent zones of the rabbit placenta. Jpn J Anim Reprod 1986; 32: 69-77 (In Japanese).

7. Kliman HJ, Nestler JE, Sermasi E, Sanger JM, Strauss III JF. Purification, characterization, and in vitro differentiation of cytotrophoblasts from human term placenta. Endocrinology 1986; 118: 1567-1582.

8. McLean IW, Nakane PK. Periodate-lysineparaformaldehyde fixative. A new fixative for immunoelectron microscopy. J Histochem Cytochem 1974; 22: 1077-1083.

9. Huong PLT, Kolk AHJ, Eggelte TA, Verstijnen CPHJ, Gilis H, Hendriks JT. Measurement of antigen specific lymphocyte proliferation using 5bromo-deoxyuridine incorporation. J Immunol Methods 1991; 140: 243-248.

10. Iguchi T, Tani N, Sato T, Fukatsu N, Ohta Y. Developmental changes in mouse placental cells from several stages of pregnancy in vivo and in vitro. Biol Reprod 1993; 48: 188-196.

11. Douglas GC, King BF. Isolation and morphologic differentiation in vitro of villous cytotrophoblast cells from rhesus monkey placenta. In Vitro Cell Dev Biol 1990; 26: 754-758.
12. Douglas GC, King BF. Isolation of pure villous cytotrophoblast from term human placenta using immunomagnetic microspheres. J Immunol Methods 1989; 119: 259-268.

13. Gratzner HG. Monoclonal antibody to 5-bromoand 5-iododeoxyuridine: a new reagent for detection of DNA replication. Science 1982; 218: 474475.

14. Hock RA, Hollenberg MD. Characterization of the receptor for epidermal growth factorurogastrone in human placenta membranes. J Biol Chem 1980; 255: 10731-10736.

15. Kawagoe K, Akiyama J, Kawamoto T, Morishita $Y$, Mori S. Immunohistochemical demonstration of epidermal growth factor (EGF) receptors in normal human placental villi. Placenta 1990; 11: 7-15.

16. Mirlesse V, Alsat E, Fondacci C, Evain-Brion D. Epidermal growth factor receptors in cultured human trophoblast cells from first- and third-trimester placentas. Horm Res 1990; 34: 234-239.

17. Mühlhauser J, Crescimanno $C$, Kaufmann $P$, Höfler H, Zaccheo D, Castellucci M. Differentiation and proliferation patterns in human trophoblast revealed by c-erbB-2 oncogene product and EGF-R. J Histochem Cytochem 1993; 41: 165-173.

18. Marshall RN, Underwood LE, Voina SJ, Foushee DB, Van Wyk JJ. Characterization of the insulin and somatomedin-c receptors in human placental cell membranes. J Clin Endocrinol Metab 1974; 39: 283-292.

19. Bhaumick B, Bala RM, Hollenberg MD. Somatomedin receptor of human placenta: solubilization, photolabeling, partial purification, and comparison with insulin receptor. Proc Natl Acad Sci USA 1981; 78: 4279-4283.

20. Pampfer S, Daiter E, Barad D, Pollard JW. Expression of the colony-stimulating factor-1 receptor (c-fms proto-oncogene product) in the human uterus and placenta. Biol Reprod 1992; 46: 48-57.

21. Uzumaki H, Okabe T, Sasaki N, Hagiwara $K$, Takaku F, Tobita M, Yasukawa K, Ito S, Umezawa $Y$. Identification and characterization of receptors for granulocyte colony-stimulating factor on human placental and trophoblastic cells. Proc Natl Acad Sci USA 1989; 86: 9323-9326. 
22. Eades DK, Cornelius P, Pekala PH. Characterization of the tumour necrosis factor receptor in human placenta. Placenta 1988; 9: 247-251.

23. Posner BI. Insulin receptors in human and animal placental tissue. Diabetes 1974; 23: 209-217.

24. Siegel TW, Ganguly S, Jacobs S, Rosen OM, Rubin CS. Purification and properties of the human placental insulin receptor. J Biol Chem 1981; 256: 9266-9273.

25. Matsuo H, Maruo T, Murata K, Mochizuki M. Human early placental trophoblasts produce an epidermal growth factor-like substance in synergy with thyroid hormone. Acta Endocrinol 1993; 128: 225-229.

26. Matsuo H, Maruo T, Murata $K$, Mochizuki $M$. Epidermal growth factor regulates trophoblast proliferation and differentiation in an autocrine/ paracrine manner. Acta Obst Gynaec Jpn 1993; 45: 23-30 (In Japanese).

27. Fant $\mathbf{M}$, Munro $\mathbf{H}$, Moses AC. An autocrine/ paracrine role for insulin-like growth factors in the regulation of human placental growth. J Clin Endocrinol Metab 1986: 63: 499-505. 